\title{
Znaczenie białka ST2 w schorzeniach układu krążenia
}

\author{
Role of ST2 in cardiovascular diseases
}

\author{
Anna Kamila Woźnicka, Marta Brzostowicz, Bożena Karolko, Wojciech Kosmala \\ Katedra i Klinika Kardiologii Uniwersytetu Medycznego we Wrocławiu
}

\section{Streszczenie}

Białko ST2 bierze udział w odpowiedzi immunologicznej i jest wydzielane w reakcji na mechaniczne rozciąganie miokardium. Jego błonowa izoforma (ST2L) stanowi receptor dla interleukiny 33, której działanie zapobiega niekorzystnej przebudowie mięśnia sercowego poprzez antagonizowanie działania angiotensyny II i amin katecholowych. sST2 stanowi rozpuszczalną formę białka, które funkcjonując jako receptor wabikowy, uniemożliwia wiązanie się IL-33 z cząsteczką ST2L i hamuje kardioprotekcyjne szlaki biochemiczne inicjowane przez IL-33. Zaburzenia równowagi pomiędzy działaniem IL33/ST2 a antagonizującym wpływem sST2 mogą sprzyjać rozwojowi miażdżycy i choroby wieńcowej oraz zmniejszać stabilność blaszki miażdżycowej, prowadząc do ostrych zespołów wieńcowych. Coraz więcej danych z prowadzonych badań sugeruje, że sST2 odgrywa istotną rolę w czynnościowym i strukturalnym remodelingu lewej komory i jej włóknieniu oraz może dostarczać cennych informacji diagnostycznych i prognostycznych w chorobach układu sercowo-naczyniowego. Dynamika seryjnych oznaczeń ST2 wskazuje na potencjalną przydatność tego biomarkera w monitorowaniu pacjentów z niewydolnością serca oraz w ocenie rokowania u chorych po zawale. W pracy przedstawiono aktualny stan wiedzy na temat udziału ST2 w patogenezie schorzeń układu krążenia ze szczególnym uwzględnieniem jego roli w niewydolności serca oraz możliwości diagnostycznych i predykcyjnych sST2 jako nowego biomarkera.

Słowa kluczowe: białko ST2, markery biologiczne, choroby sercowo-naczyniowe, niewydolność serca

Folia Cardiologica 2016; 11, 4: 303-309

\section{Wstęp}

Pomimo powszechnego użycia różnorodnych markerów biochemicznych, w tym peptydów natriuretycznych i troponin, w dalszym ciągu istnieje potrzeba poszukiwania nowych wskaźników, które usprawniłyby proces decyzyjny w praktyce klinicznej, nie tylko przyczyniając się do postawienia właściwego rozpoznania, ale również ułatwiając śledzenie postępu choroby i efektów wdrożonego leczenia oraz określając krótko- i długoterminowe rokowanie. Jedną z nowych cząsteczek będących w kręgu zainteresowań jest ST2 (suppression of tumorigenicity 2) - białko biorące udział w odpowiedzi immunologicznej, wydzielane w reakcji na mechaniczne rozciąganie miokardium. Coraz więcej danych z prowadzonych badań wskazuje, że ST2 może być unikatowym markerem diagnostycznym, który charakteryzuje procesy przebudowy i włóknienia mięśnia sercowego oraz przede wszystkim dostarcza cennych informacji prognostycznych.

\section{Znaczenie biologiczne i rola ST2 w patofizjologii chorób sercowo-naczyniowych}

Białko ST2 należy do rodziny receptorów interleukiny 1 (IL-1). Występuje w 4 izoformach, z których 2 mają istotne znaczenie kliniczne: błonowa (ST2L lub ligand ST2) oraz rozpuszczalna, krążąca w surowicy (sST2, soluble ST2). Oba białka są kodowane przez gen ST2 znajdujący się na chromosomie $2 q 12$, a różnice w ich budowie i ilości są wyni-

Adres do korespondencji: prof. dr hab. n. med. Wojciech Kosmala, Katedra i Klinika Kardiologii Uniwersytetu Medycznego we Wrocławiu, ul. Borowska 213, 50-556 Wrocław, tel. 7173642 00, e-mail: wojciech.kosmala@umed.wroc.pl 
kiem alternatywnego splicingu - procesu obróbki posttranskrypcyjnej pre-mRNA prowadzącego do powstania 2 różnych cząsteczek białka [1]. Białko błonowe ST2L składa się z 3 zewnątrzkomórkowych domen dla immunoglobulin G, pojedynczej domeny przezbłonowej i domeny wewnątrzkomórkowej [1]. Rozpuszczalna forma sST2 w swojej budowie nie ma domeny przezbłonowej ani wewnątrzkomórkowej i krąży swobodnie we krwi. Pobudzenie receptora błonowego ST2L powoduje aktywację limfocytów Th2 i zwiększoną produkcję cytokin, takich jak interleukina 4, 5 i 13, które wzmacniają odpowiedź immunologiczną limfocytów Th2 na procesy zapalne [2]. Czynnościowym ligandem receptora ST2 jest interleukina 33 (IL-33). Bodźce mechaniczne w postaci rozciągania kardiomiocytów i fibroblastów sercowych wywołują zarówno zwiększone uwalnianie IL-33 z pęcherzyków cytoplazmatycznych [3], jak i zwiększoną ekspresję ST2L i sST2 [4, 5]. Wiązanie się IL-33 z ST2L w odpowiedzi na zadziałanie czynnika patologicznego, takiego jak wzrost obciążenia lub niedokrwienie miokardium, wywołuje efekt kardioprotekcyjny. Wykazano, że interakcja IL-33 z ST2L przeciwdziała przebudowie mięśnia sercowego poprzez antagonizowanie działania angiotensyny II i amin katecholowych, a mechanizmem w tym pośredniczącym jest hamowanie aktywności czynnika transkrypcyjnego NF- $\kappa \mathrm{B}$, kinaz aktywowanych mitogenami (MAPK, mitogen-activated protein kinases) i fosforylacji kinazy IKK [5].

Rozpuszczalna izoforma ST2 funkcjonuje jako receptor wabikowy (decoy receptor), uniemożliwiając wiązanie się IL-33 z cząsteczką ST2L, czego efektem jest zmniejszenie się (down-regulation) odpowiedzi immunologicznej IL-33 [5]. Dodatkowo sST2 pod wpływem krążącego we krwi bakteryjnego lipopolisacharydu (LPS) może również łączyć się bezpośrednio z makrofagami, zmieniając ich odpowiedź immunologiczną w postaci blokady produkcji cytokin, między innymi interleukiny 6 (IL-6), interleukiny 12 oraz czynnika martwicy nowotworów alfa (TNF- $\alpha$, tumor necrosis factor alpha) [6]. Nadmierne stężenie sST2 w surowicy obniża kardioprotekcyjne działanie IL-33, skutkując wzrostem ryzyka niekorzystnych zmian w zakresie struktury i funkcji serca. Efekt biologiczny ST2 zależy więc od równowagi pomiędzy błonową i rozpuszczalną formą cząsteczki.

Złożoność regulacji stężenia obu form ST2 w kontekście odpowiedzi immunologicznej wiąże się z istnieniem wzajemnych zależności pomiędzy komórkami układu immunologicznego, produkowanymi przez nie cytokinami oraz ekspresją ST2. Jedynie część mnogich powiązań została dotychczas poznana. Wykazano, że IL-6 podwyższa stężenie ST2 podczas różnicowania limfocytów Th2. Prawdopodobnie również ST2 jest w stanie aktywować niezróżnicowane limfocyty T do rozwoju w kierunku limfocytów T typu 2, a równocześnie system immunologiczny wzmaga ekspresję ST2 [1].

Wpływ przekaźnictwa IL-33/ST2 na naczynia tętnicze jest złożony i niejednoznaczny. Z jednej strony wykazano, że eksperymentalne podawanie IL-33 hamowało rozwój miażdżycy i tworzenie komórek piankowatych, a aplikacja białka sST2 blokującego wpływ IL-33 wywoływała efekt przeciwny [7], z drugiej strony jednak istnieją doniesienia, które podkreślają rolę IL-33 w wywoływaniu wczesnej miażdżycy poprzez promowanie angiogenezy i dysfunkcji śródbłonka [8]. W badaniach klinicznych wykazano, że ekspresja IL-33 i ST2 jest podwyższona w tkance tłuszczowej osób otyłych. Z kolei w surowicy u tych osób stwierdzono podwyższone stężenie sST2, ale nie IL-33. Zaburzenia równowagi pomiędzy działaniem IL-33/ST2 a hamującym wpływem sST2 mogą sprzyjać rozwojowi miażdżycy i choroby wieńcowej, co wydaje się szczególnie istotnym mechanizmem patofizjologicznym w tej grupie chorych [9].

Przekaźnictwo IL-33/ST2 nie tylko wpływa na proces tworzenia się blaszki miażdżycowej, ale też reguluje jej stabilność hemodynamiczną. Dowiedziono, że interferon $\gamma$ produkowany przez limfocyty Th1 wzmaga produkcję metaloproteinaz macierzy zewnątrzkomórkowej, które moga zniszczyć włóknistą czapeczkę blaszki miażdżycowej, powodując powstanie blaszki niestabilnej [10]. Interleukina 33, obniżając stężenia interferonu $\mathrm{y}$, zapobiega aktywacji metaloproteinaz i stabilizuje blaszkę miażdżycową [6]. Ten protekcyjny efekt IL-33 ulega osłabieniu w czasie ostrego zawału serca, kiedy w surowicy krwi stwierdza się podwyższone stężenie sST2 i obniżone stężenie IL-33 [4].

Wyniki badań in vitro i in vivo wykazały, że IL-33 odgrywa kluczową rolę w regulacji homeostazy mięśnia sercowego po zawale [7]. W badaniach na szczurach udowodniono, że IL-33 poprzez blokowanie kaspazy 3 oraz wzrost ekspresji białek z rodziny IAP (inhibitors of apoptosis) zapobiega apoptozie w hodowlach kardiomiocytów poddanych niedokrwieniu. Dodatkowo stwierdzono, że podskórne wstrzyknięcie IL-33 po podwiązaniu tętnic wieńcowych redukowało objętość mięśnia objętego zawałem, włóknienie oraz apoptozę kardiomiocytów. Podanie sST2 z kolei nasilało powyższe procesy poprzez blokowanie działania IL-33, a wywołany skutek był zależny od podanej dawki białka [11].

Korzystny wpływ IL-33 na strukturalną i czynnościową przebudowę serca w przebiegu chorób sercowo-naczyniowych wyraża się zarówno hamowaniem włóknienia miokardium, jak i redukcją przerostu kardiomiocytów [5]. Wzrost stężenia sST2 może poprzez antagonizowanie efektu IL-33 na przebudowę macierzy pozakomórkowej pogarszać przewodnictwo elektryczne pomiędzy kardiomiocytami z następowym powstawaniem groźnych arytmii, w tym częstoskurczów komorowych i migotania komór.

\section{Białko ST2 jako biomarker}

Cenną zaletą ST2 przy rozważaniu zastosowania tego białka jako biomarkera są stosunkowo szybkie zmiany jego stężenia w surowicy, dostosowujące się do aktualnego stanu klinicznego pacjenta. Należy pamiętać, że w związku 
z dużą złożonością genetycznego zapisu regulacji syntezy, istnieje znaczna zmienność osobnicza stężenia sST2 [3]. Przy podejmowaniu oceny diagnostycznej i rokowniczej w chorobach układu krążenia na podstawie sST2 należy uwzględnić sytuacje, które mogą spowodować wzrost jego stężenia, takie jak interwencje sercowo-naczyniowe (pomostowanie aortalno-wieńcowe, angioplastyki wieńcowe, chirurgia tętnic obwodowych) [12]. Zwiększone stężenia sST2 wykazano u mężczyzn, osób w wieku podeszłym, pacjentów z nadciśnieniem tętniczym, cukrzycą oraz chorobami zapalnymi i alergicznymi, takimi jak posocznica, eozynofilowe zapalenie płuc, przewlekła obturacyjna choroba płuc (POChP), astma, zwłóknienie płuc i toczeń rumieniowaty układowy $[13,14]$. Wyniki badań oceniających wpływ funkcji nerek na stężenie sST2 są niejednoznaczne.

\section{Wartość diagnostyczna}

Udział ST2 w procesach patofizjologicznych leżących u podstaw chorób sercowo-naczyniowych stwarza przesłanki do wykorzystania tego białka w diagnostyce klinicznej. Podwyższone stężenia ST2 cechowały chorych z epizodem zaostrzonej niewydolności serca, co było pomocne w różnicowaniu duszności pochodzenia sercowego i pozasercowego [15]. Możliwości praktycznego zastosowania ST2 z takim przeznaczeniem wydają się jednak ograniczone wobec większej czułości w tym zakresie N-końcowego propeptydu natriuretycznego typu B (NT-proBNP, N-terminal pro-B-type natriuretic peptide).

W populacji chorych z niewydolnością serca wykazano, że pacjenci z obniżoną frakcją wyrzutową lewej komory charakteryzują się wyższymi stężeniami ST2 w porównaniu z chorymi z zachowaną frakcją wyrzutową (HFpEF, heart failure with preserved ejection fraction) [15]. Wyniki pojedynczych badań sugeruja przewagę ST2 nad NT-proBNP w wykrywaniu HFpEF, pomimo większego potencjału diagnostycznego peptydu natriuretycznego w przypadku obecności podwyższonego ciśnienia napełniania lewej komory. Analiza w grupie chorych z nadciśnieniem tętniczym wykazała, że stężenie sST2 powyżej ustalonego progu $13,5 \mathrm{ng} / \mathrm{ml}$ było niezależnym czynnikiem pozwalającym na identyfikację HFpEF [16].

Kwantyfikacja ST2 ma dużą wartość diagnostyczną w różnicowaniu przyczyn wstrząsu. Wykazano, że stężenia sST2 są znacząco wyższe we wstrząsie septycznym niż we wstrząsie kardiogennym, przy czym wartości przekraczające 210,4 ng/ml zostały opisane jako z dużym prawdopodobieństwem określające wstrząs septyczny [17].

Pomiar stężenia sST2 może być użytecznym sposobem rozpoznawania wczesnego odrzucenia przeszczepu serca. Stwierdzono, że sST2 rośnie znacząco w potwierdzonych biopsją endomiokardialną przypadkach odrzucania przeszczepu w 1 roku po transplantacji serca. Wykorzystanie
sST2 łącznie z NT-proBNP znacząco poprawia biochemiczną identyfikację odrzucenia [18].

Zwiększoną syntezę ST2, zależną od stopnia rozstrzeni i zaburzeń czynności skurczowej prawej komory, wykazano u chorych z nadciśnieniem płucnym $[19,20]$. Pacjenci ze znacznie podwyższonymi wartościami sST2 wykazywali większe nasilenie choroby z bardziej upośledzoną tolerancją wysiłku oraz większy stopień dysfunkcji i remodelingu prawej komory. Ponadto u chorych z wysokim stężeniem sST2 i nadciśnieniem płucnym stwierdzono większe nasilenie procesów włóknienia miokardium ocenianego na podstawie techniki rezonansu magnetycznego (MRI, magnetic resonance imaging). Nasilone włóknienie potwierdzone w MRI u pacjentów ze znamiennie podwyższonym stężeniem ST2 wykazały również wyniki badań, które zajmowały się populacjami pacjentów po zawale serca [21].

\section{Wartość prognostyczna}

Badania przeprowadzone w populacji ogólnej i osób zdrowych dowodzą, że obecność podwyższonego stężenia sST2 może być czynnikiem predykcyjnym rozwoju chorób sercowo-naczyniowych. Rolę prognostyczną SST2 wykazano podczas 3-letniej obserwacji populacji Framingham Heart Study, w której wyższe wartości markera wiązały się z tendencją do stopniowego wzrostu skurczowego ciśnienia tętniczego i ciśnienia tętna [13]. W innej pracy stężenie sST2 u potencjalnie zdrowych osób prognozowało ryzyko zgonu i niewydolności serca w ciągu kolejnych 11 lat obserwacji [22]. Zastosowanie w analizie dodatkowych biomarkerów - czynnika różnicowania wzrostu 15 (GDF-15, growth differentiation factor) i wysoce czułej troponiny I (hsTnl) pozwoliło na rozszerzenie wartości prognostycznej również o ryzyko incydentów choroby wieńcowej. Wyższe stężenie sST2 było związane ze wzrostem prawdopodobieństwa ryzyka zgonu z przyczyn-sercowo naczyniowych w badaniu Dallas Heart Study obejmującym populację ogólną [14].

Wartość predykcyjną SST2 w prognozowaniu krótkoterminowego ryzyka zgonu wykazano też w grupie osób ambulatoryjnie zgłaszających się na badanie echokardiograficzne [23]. Stężenie ST-2 było niezależnym wskaźnikiem śmiertelności 1-rocznej determinującym również częstość serca, funkcję nerek, konieczność stosowania leków i kurczliwość prawej komory.

\section{Niewydolność serca}

Przydatność rokowniczą ST2 wykazano w szeregu prac analizujących pacjentów z ostrą i przewlekłą niewydolnością serca. W badaniu PRIDE ST2 przewyższało BNP w predykcji 12-miesięcznego ryzyka zgonu w grupie chorych diagnozowanych z powodu duszności. W innej analizie najwyższe stężenie ST2 charakteryzowało chorych z dusznością 
sercowopochodną, którzy zmarli do 30 dni po epizodzie zaostrzenia choroby (mediana sST2 $124 \mathrm{ng} / \mathrm{ml}$ ), a nieco niższe - osoby, u których zgon nastąpił w okresie do 12 miesięcy (mediana $91 \mathrm{ng} / \mathrm{ml}$ ). Największą 1-roczną śmiertelność obserwowano w przypadku podwyższenia zarówno stężeń NT-proBNP, jak i sST2. Pacjenci, u których obydwa biomarkery wykazywały niskie stężenie, charakteryzowali się najlepszym rokowaniem [15].

W dużym badaniu oceniającym wartość prognostyczną markerów sercowych takich jak sST2, MR-proADM (mid-regional pro-adrenomedullin), peptydów natriuretycznych (NT-proBNP i BNP), białka C-reaktywnego (CRP, C-reactive protein) i MR-proANP (mid-regional pro-atrial natriuretic peptide) wykazano, że sST2 najtrafniej obok MR-proADM przewidywał ryzyko zgonu po epizodzie ostrej niewydolności serca w pierwszych 30 dniach po dekompensacji [24].

Dynamika zmian syntezy i uwalniania ST2 koreluje z przebiegiem klinicznym niewydolności serca, z wyższymi stężeniami markera towarzyszącymi większemu nasileniu objawów chorobowych i gorszemu profilowi hemodynamicznemu wyrażonemu wyższym ośrodkowym ciśnieniem żylnym i ciśnieniem zaklinowania. Każde podwojenie stężenia ST2 wiąże się ze wzrostem ryzyka zgonu lub transplantacji serca o 40-50\%. Implementacja ST2 i NT-proBNP do Seattle Heart Failure Model score (SHFM score) poprawiała o około 15\% trafność klasyfikacji pacjentów do odpowiednich grup ryzyka [25].

Śledzenie zmian stężenia sST2 wydaje się użyteczne w celu oceny rokowania w trakcie leczenia. Wykazano, że spadek stężenia SST2 podczas hospitalizacji pacjentów z ostrą niewydolnością serca koreluje ze spadkiem ryzyka zgonu [26]. Białko ST2 może być przydatnym narzędziem w predykcji odpowiedzi na terapię beta-adrenolitykami. Korzystny wpływ tej grupy leków na przeżywalność pacjentów z epizodami zaostrzenia niewydolności serca wykazano jedynie u chorych bez istotnego spadku stężenia sST2 po 2 dobach od początku hospitalizacji [26]. Pomiar stężenia sST2 może również ułatwić prowadzenie terapii beta-adrenolitykami w przewlekłej niewydolności serca, w związku z wykazanym spadkiem stężenia tego markera w trakcie zwiększania dawki beta-adrenolityku [27].

Okresowa kontrola stężenia ST2 u osób z przewlekłą niewydolnością serca może być pomocna w identyfikacji pacjentów szczególnie narażonych na niekorzystną przebudowę lewej komory. Wykazano związek pomiędzy zmianami stężenia ST2 w seryjnych oznaczeniach a późniejszym pogorszeniem funkcji skurczowej lewej komory. Analogicznej zależności nie stwierdzono w przypadku seryjnych oznaczeń NT-proBNP, GDF-15 czy troponin o wysokiej czułości (hsTnT) [27].

Ważnym elementem szeroko pojętej terapii chorych z niewydolnością serca jest propagowanie i wdrażanie aktywności fizycznej. Autorzy badania HF-ACTION wykazali, że wprowadzenie regularnego cyklu ćwiczeń służy bardziej pacjentom z niższym stężeniem sST2 [28]. Grupa ta jest mniej narażona na ponowną hospitalizację i to właśnie ona odnosi najwięcej korzyści z tego typu uzupełnienia podstawowych form leczenia.

Podwyższone stężenie sST2 jest czynnikiem determinującym ryzyko nagłej śmierci sercowej w niewydolności serca, dostarczając dodatkowych informacji w stosunku do peptydów natriuretycznych. Analiza populacji z badania MUSIC obejmującego pacjentów w klasie czynnościowej New York Hart Association (NYHA) I-III z frakcją wyrzutową lewej komory poniżej 45\% wykazała wysoką ujemną wartość predykcyjną zarówno sST2, jak i NT-proBNP w określaniu zagrożenia nagłym zgonem. Stwierdzono, że tylko $4 \%$ pacjentów, którzy doświadczyli nagłej śmierci sercowej, charakteryzowało się podwyższonymi stężeniami obu markerów [29].

Białko ST2 i peptydy natriuretyczne wspólnie identyfikują grupę pacjentów z zaawansowaną niewydolnością serca, u których krótkoterminowe ryzyko zgonu pomimo obecności kardiowertera-defibrylatora (ICD, implantable cardioverter defibrillator) jest duże. Są to osoby, którym implantacja układu ICD istotnie nie przedłuży życia i pomimo skutecznych interwencji urządzenia umrą w niedługim czasie w przebiegu zaawansowanej niewydolności serca [30].

\section{Choroba niedokrwienna serca}

Stężenie ST2 wzrasta w pierwszych kilkunastu godzinach zawału serca i jest niezależnym czynnikiem predykcyjnym zgonu i rozwoju niewydolności serca we wczesnym (30 dni) i późnym (1 rok) okresie pozawałowym [31, 32]. Informacja prognostyczna pochodząca z pomiaru ST2 przewyższa analogiczne dane wynikające z oceny frakcji wyrzutowej lewej komory, stanu hemodynamicznego pacjenta czy stężenia troponin lub BNP [14]. Ważną właściwością ST2 jako markera, odróżniającą go od peptydów natriuretycznych, jest niezależność jego zmian okołozawałowych od wieku chorego, współistnienia nadciśnienia tętniczego, wcześniej przebytych incydentów wieńcowych i wcześniejszej niewydolności serca. W analizie szeregu badań wykazano, że ST-2 prognozuje w populacji pozawałowej ryzyko zgonu i rozwoju niewydolności serca, ale nie ryzyko nawrotu incydentów wieńcowych [33].

Dołączenie ST2 do TIMI Risk Score znacząco polepszało stratyfikację ryzyka w grupie chorych z zawałem serca z uniesieniem odcinka ST, natomiast próba wprowadzenia ST2 do skali GRACE nie przyczyniła się istotnie do lepszej oceny rokowniczej pacjentów z zawałem serca bez uniesienia odcinka ST [32].

Z uwagi na patofizjologiczną rolę w procesach zmian strukturalnych i czynnościowych będących następstwem zawału, ST2 może być wartościowym narzędziem w straty- 
fikacji ryzyka niekorzystnej pozawałowej przebudowy lewej komory. W pracy badającej pacjentów po ostrym zawale serca wyjściowe stężenie SST2 korelowało z wielkością i stopniem pełnościenności zawału, uszkodzeniem mikrokrążenia wieńcowego oraz rozstrzenią i dysfunkcją lewej komory [21]. Dynamika spadku stężenia ST2 w okresie pozawałowym wiązała się z progresją zaburzeń funkcji i morfologii serca. Wykazano również potencjalną przydatność ST2 w identyfikacji pacjentów największego ryzyka pozawałowej przebudowy serca, którzy mają największą szansę na odniesienie korzyści z leczenia antagonistami receptora aldosteronu. Zaobserwowano, że efekt eplerenonu przeciwdziałania niekorzystnemu remodelingowi był silnej wyrażony u pacjentów z wysokim stężeniem sST2 przy przyjęciu [21]. Zastosowanie antagonistów aldosteronu obniżało ekspresję ST2 w obrębie miokardium objętego zawałem, co może być jednym z mechanizmów korzystnego wpływu tych leków na przebudowę lewej komory serca [34].

\section{Zabiegi kardiochirurgiczne}

Nieoczekiwane wnioski przyniosła praca dotycząca wykorzystania ST2 w ocenie rokowania u pacjentów poddanych operacji kardiochirurgicznej z powodu niedomykalności zastawki mitralnej. Korzystny efekt zabiegu w badaniu wykonanym po 6 miesiącach w postaci regresji rozstrzeni lewej komory i poprawy jej funkcji skurczowej częściej wiązał się z wyższymi wyjściowymi stężeniami ST2 [35]. Wyniki te należy rozpatrywać w szerszym aspekcie, biorąc pod uwage złożoność reakcji immunologicznych towarzyszących operacji na otwartym sercu z użyciem krążenia pozaustrojowego, które mogły obejmować zwiększone przekaźnictwo IL-33/ ST2 z kardioprotekcyjnym działaniem IL-33. Ten kierunek zastosowań predykcyjnych ST2 jest na etapie początkowych badań i wymaga dalszej skrupulatnej oceny.

\section{Podsumowanie}

Identyfikacja nowych biomarkerów, pozwalająca na lepszą diagnostykę, monitorowanie oraz ocenę ryzyka, jest najważniejszym krokiem ułatwiającym dostosowanie leczenia i dalszych zabiegów terapeutycznych, co z kolei skutkuje lepszą jakością życia i zapobiega przedwczesnym zgonom. Obecny stan wiedzy i świadomość złożoności procesów patofizjologicznych wywołujących określone jednostki chorobowe wskazują, że nie istnieje jeden uniwersalny marker chorób sercowo-naczyniowych. Główną wadą cząsteczek do tej pory odkrytych jest ich mała swoistość, co w praktyce przekłada się na konieczność korzystania z wielu markerów jednocześnie w celu uzyskania optymalnej wiedzy prognostycznej i diagnostycznej. Wartość SST2 została doceniona w wytycznych amerykańskich towarzystw kardiologicznych (American College of Cardiology, American Heart Association) z 2013 roku dotyczących niewydolności serca. Przedstawiono tam sST2 jako biomarker przewidujący ryzyko zgonu i ponownej hospitalizacji u pacjentów z niewydolnością serca, szczególnie ważny w zastosowaniu łącznie z peptydami natriuretycznymi. W praktyce klinicznej oznaczanie sST2 wydaje się zasadne w monitorowaniu pacjentów z niewydolnością serca w celu prognozowania przebiegu choroby oraz wyselekcjonowania pacjentów obciążonych wysokim ryzykiem zgonu i ponownej hospitalizacji, którzy mogliby odnieść korzyść z intensywniejszej terapii, niż by to wynikało z oceny klasycznych czynników rokowniczych. Dodatkowo nowy biomarker mógłby być użyteczny w diagnostyce niewydolności serca z zachowaną frakcją skurczową lewej komory, w której czułość wykorzystywanych powszechnie metod laboratoryjnych wydaje się niedostateczna. U chorych po zawale serca oznaczanie sST2 może dostarczyć cennych informacji prognostycznych dotyczących ryzyka wystąpienia niekorzystnych zdarzeń sercowo-naczyniowych oraz czynnościowej i strukturalnej przebudowy lewej komory. W przypadku pacjentów wymagających intensywnej terapii medycznej szczególnie przydatne wydaje się zastosowanie sST2 w diagnozowaniu i monitorowaniu pacjentów z posocznicą, ciężką niewydolnością serca i po przeszczepie serca. Przyszłe badania odpowiedzą na pytanie, czy możliwa będzie bezpośrednia interwencja terapeutyczna skierowana na szlak ST2/IL-33, która mogłaby przeciwdziałać niekorzystnemu remodelingowi mięśnia sercowego.

\section{Konflikt interesów}

Autorzy nie zgłaszają konfliktu interesów. 


\section{Abstract}

ST2 is a protein involved in the immunological processes, which is synthesized and released in response to mechanical stress imposed on the myocardium. Its membrane-bound isoform (ST2L) is a receptor for Interleukin-33, which prevents the negative effect of myocardial remodeling by antagonizing the action of angiotensin II and catecholamines. Soluble isoform of ST2 (SST2) is a blood protein that by acting as a decoy receptor reduces cardioprotective effects of IL-33. Disproportion between the IL-33/ST2 signaling and the opposite effect exerted by SST2 may favor the development of atherosclerosis, coronary heart disease and reduce the stability of atherosclerotic plaques, leading to acute coronary syndromes. Accumulating evidence suggests that SST2 plays a pivotal role in left ventricular structural and functional remodeling and myocardial fibrosis and may provide valuable diagnostic and prognostic information in cardiovascular disorders. Dynamic changes in SST2 concentration suggest the potential usefulness of this biomarker in monitoring patients with heart failure and in predicting cardiovascular risk in post-infarct patients. This review summarizes the most recent advances in ST2 research in the field of cardiovascular disease with special focus on its role in heart failure, and diagnostic and prognostic significance.

Key words: ST2 protein, biological markers, cardiovascular diseases, heart failure

Folia Cardiologica 2016; 11, 4: 303-309

\section{Piśmiennictwo}

1. Ciccone M.M., Cortese F., Gesualdo M. i wsp. A novel cardiac bio-marker: ST2: a review. Molecules 2013; 18: 15314-15328.

2. Schmitz J., Owyang A., Oldham E. i wsp. IL-33, an interleukin-1- like cytokine that signals via the IL-1 receptor related protein ST2 and induces T helper type 2-associated cytokines. Immunity 2005; 23 : 479-490.

3. Kakkar R., Hei H., Dobner S., Lee R.T. Interleukin 33 as a mechanically response cytokine secreted by living cells. J. Biol. Chem. 2012; 287: 6941-6948.

4. Weinberg E.O., Shimpo M., De Keulenaer G.W. i wsp. Expression and regulation of ST2, an interleukin-1 receptor family member, in cardiomyocytes and myocardial infarction. Circulation 2002; 106 : 2961-2966.

5. Sanada S., Hakuno D., Higgins L.J. i wsp. IL-33 and ST2 comprise a critical biomechanically induced and cardioprotective signaling system. J. Clin. Invest. 2007; 117: 1538-1549.

6. Sweet M.J., Leung B.P., Kang D. i wsp. A novel pathway regulating lipopolysaccharide-induced shock by ST2/T1 via inhibition of Toll-like receptor 4 expression. J. Immunol. 2001; 166: 6633-6639.

7. Miller A.M., Xu D., Asquith D.L. i wsp. IL-33 reduces the development of atherosclerosis. J. Exp. Med. 2008; 205: 339-346.

8. Demyanets S., Konya V., Kastl S.P. i wsp. Interleukin-33 induces expression of adhesion molecules and inflammatory activation in human endothelial cells and in human atherosclerotic plaques. Arterioscler. Thromb. Vasc. Biol. 2011; 31: 2080-2089.

9. Zeyda M., Wernly B., Demyanets S. i wsp. Severe obesity increases adipose tissue expression of interleukin-33 and its receptor ST2, both predominantly detectable in endothelial cells of human adipose tissue. Int. J. Obes. 2013; 37: 658-665.

10. Baida S.G., Zeng Q.T. Helper T cells and atherosclerosis: The cytokine Web. Postgrad. Med. J. 2015; 81: 746-752.

11. Seki K., Sanada S., Kudinova A.Y. i wsp. Interleukin-33 prevents apoptosis and improves survival after experimental myocardial infarction through ST2 signaling. Circ. Heart Fail. 2009; 2: 684-691.
12. Willems S., Sels J.W., Flier S. i wsp. Temporal changes of soluble ST2 after cardiovascular interventions. Eur. J. Clin. Invest. 2013; 43: 113-120.

13. Coglianese E.E., Larson M.G., Vasan R.S. i wsp. Distribution and clinical correlates of the interleukin receptor family member soluble ST2 in the Framingham Heart Study. Clin. Chem. 2012; 58: 1673-1681.

14. Chen L.Q., de Lemos J.A., Das S.R. i wsp. Soluble ST2 is associated with all-cause and cardiovascular mortality in a population-based cohort: the Dallas Heart Study. Clin. Chem. 2013; 59: 536-546.

15. Januzzi J.L. Jr, Peacock W.F., Maisel A.S. i wsp. Measurement of the interleukin family member ST2 in patients with acute dyspnea: results from the PRIDE (Pro-Brain Natriuretic Peptide Investigation of Dyspnea in the Emergency Department) study. J. Am. Coll. Cardiol. 2007; 50: 607-613.

16. Wang Y.C., Yu C.C., Chiu F.C. i wsp. Soluble ST2 as a biomarker for detecting stable heart failure with a normal ejection fraction in hypertensive patients. J. Card. Fail. 2013; 19: 163-168.

17. Parenica J., Malaska J., Jarkovsky J. i wsp. Soluble ST2 levels in patients with cardiogenic and septic shock are not predictors of mortality. Exp. Clin. Cardiol. 2012; 17: 205-209.

18. Pascual-Figal D.A., Garrido I.P., Blanco R. i wsp. Soluble ST2 is a marker for acute cardiac allograft rejection. The Annals of Thoracic Surgery 2011; 92: 2118-2124.

19. Carlomagno G., Messalli G., Melillo R.M. i wsp. Serum soluble ST2 and interleukin-33 levels in patients with pulmonary arteria hypertension. Int. J. Cardiol. 2013; 168: 1545-1547.

20. Zheng Y.G., Yang T., He J.G. i wsp. Plasma soluble ST2 levels correlate with disease severity and predict clinical worsening in patients with pulmonary arterial hypertension. Clin. Cardiol. 2014; 37: 365-370.

21. Weir R.A.P., Miller A.M., Murphy G.E.J. i wsp. Serum soluble ST2: a potential novel mediator in left ventricular and infarct remodeling after acute myocardial infarction. J. Am. Col. Cardiol. 2010; 55: 243-250.

22. Wang T.J., Wollert K.C., Larson M.G. i wsp. Prognostic utility of novel biomarkers of cardiovascular stress: the Framingham Heart Study. Circulation 2012; 126: 1596-1604. 
23. Daniels L.B., Clopton P., Iqbal N. i wsp. Association of ST2 levels with cardiac structure and function and mortality in outpatients. Am. Heart J. 2010; 160: 721-728.

24. Lassus J., Gayat E., Mueller C. i wsp. Incremental value of biomarkers to clinical variables for mortality prediction in acutely decompensated heart failure: the Multinational Observational Cohort on Acute Heart Failure (MOCA) study. Int. J. Cardiol. 2013; 168: 2186-2194.

25. Ky B., French B., McCloskey K. i wsp. High-sensitivity ST2 for prediction of adverse outcomes in chronic heart failure. Circ. Heart Fail. 2011; 4: 180-187.

26. Breidthardt T., Balmelli C., Twerenbold R. i wsp. Heart failure therapyinduced early ST2 changes may offer long-term therapy guidance. J. Card. Fail. 2013; 19: 821-828.

27. Gaggin H.K., Szymonifka J., Bhardwaj A. i wsp. Head-to-head comparison of serial soluble ST2, growth differentiation factor-15, and highly-sensitive troponin $\mathrm{T}$ measurements in patients with chronic heart failure. JACC Heart Fail. 2014; 2: 65-72.

28. Felker G.M., Fiuzat M., Thompson V. i wsp. Soluble ST2 in ambulatory patients with heart failure: Association with functional capacity and long-term outcomes. Circ. Heart Fail. 2013; 6: 1172-1179.

29. Pascual-Figal D.A., Ordoñez-Llanos J., Tornel P.L. i wsp. Soluble ST2 for predicting sudden cardiac death in patients with chronic heart failure and left ventricular systolic dysfunction. J. Am. Coll. Cardiol. 2009; 54: 2174-2179.

30. Scott P.A., Townsend P.A., Ng L.L. i wsp. Defining potential to benefit from implantable cardioverter defibrillator therapy: the role of biomarkers. Europace 2011; 13: 1419-1427.

31. Demyanets S., Speidl W.S., Tentzeris I. i wsp. Soluble ST2 and interleukin-33 levels in coronary artery disease: relation to disease activity and adverse outcome. PLoS One 2014; 9: e95055.

32. Dhillon O.S., Narayan H.K., Quinn P.A. i wsp. Interleukin 33 and ST2 in non-ST-elevation myocardial infarction: Comparison with global registry of acute coronary events risk scoring and NT-proBNP. Am. Heart J. 2011; 161: 1163-1170.

33. Richards M.A., Di Somma S., Mueller T. ST2 in Stable and Unstable Ischemic Heart Diseases. Am. J. Cardiol. 2015; 115 (supl.): 48B-58B.

34. Lax A., Sanchez-Mas J., Asensio-Lopez M.C. i wsp. Mineralocorticoid receptor antagonists modulate galectin-3 and interleukin-33/ST2 signaling in left ventricular systolic dysfunction after acute myocardial infarction. JACC Heart Fail. 2015; 3: 50-58.

35. Galeone A., Lessana A., Mascolo E. i wsp. Interleukin-1 receptorrelated protein ST2 and mitral valve repair outcome in patients with chronic degenerative mitral regurgitation. Thorac. Cardiovasc. Surg. 2014; 62: 47-51. 